\title{
Ileal digestibility of dietary protein in the growing pig and adult human
}

\author{
Amélie Deglaire ${ }^{1,2}$, Cécile Bos $^{2}$, Daniel Tomé ${ }^{2}$ and Paul J. Moughan ${ }^{1 *}$ \\ ${ }^{1}$ Riddet Institute, Massey University, Private Bag 11222, Palmerston North, New Zealand \\ ${ }^{2}$ INRA, AgroParisTech, UMR914 Nutrition Physiology and Ingestive Behaviour, CRNH-IdF, 75005 Paris, France
}

(Received 18 December 2008 - Revised 2 July 2009 - Accepted 3 July 2009 - First published online 26 August 2009)

The suitability of the pig as an animal model for predicting protein digestibility in man was evaluated. Healthy adult human subjects (mean body weight $67 \mathrm{~kg} ; n$ 11) and growing pigs (mean body weight $40 \mathrm{~kg} ; n 15$ ) were fed semi-synthetic mixed meals containing, as a sole source of $\mathrm{N}$, casein $(\mathrm{C})$, hydrolysed casein (HC) or rapeseed isolate (R). There was no prior adaptation to the test meal. Ileal digesta were sampled through a naso-ileal tube (human subjects) or a post-valve T-caecum cannula (pigs) after ingestion of a bolus meal. The protein sources were ${ }^{15} \mathrm{~N}-$ labelled. Amino acid (AA) digestibilities were not determined for R. Ileal apparent N digestibility was markedly lower $(14-16 \% ; P<0 \cdot 001)$ in human subjects than in pigs $(\mathrm{C}, \mathrm{HC}, \mathrm{R})$. Similarly, most apparent ileal AA digestibilities were lower $(8 \%$ on average; $P<0.05)$ in human subjects $(\mathrm{C}, \mathrm{HC})$. Ileal true $\mathrm{N}$ digestibility was slightly lower $(3-5 \% ; P<0.001)$ in human subjects than in pigs $(\mathrm{C}, \mathrm{HC}, \mathrm{R})$ and most true ileal AA digestibilities were similar $(P>0.05)$ between the species $(\mathrm{C}, \mathrm{HC})$. Exceptions were for phenylalanine, tyrosine, lysine, histidine and aspartic acid for which digestibilities were lower ( $3 \%$ on average; $P<0 \cdot 001)$ in human subjects. A similar ranking of the diets was observed for true ileal $\mathrm{N}$ digestibility between species. The inter-species correlation for true ileal digestibility was high for $\mathrm{N}(r 0.98$ over $3 \times 2$ data; $P=0.11)$ and AA $(r 0.87$ over $26 \times 2$ data; $P<0.0001)$. Overall, this supports the use of the pig as a model for predicting differences among dietary protein digestibility, especially regarding true ileal $\mathrm{N}$ digestibility, in man.

Human adults: Pigs: Digestibility: Ileal digestibility: Protein

The digestibility of dietary protein, an indirect measure of the extent of digestion and absorption of food protein as amino acids (AA), is a key determinant of protein bioavailability ${ }^{(1)}$. It is thus considered as an important factor for nutritional quality assessment ${ }^{(2)}$. It is important to determine protein digestibility with accuracy as it differs substantially among diets, in particular between those from developing or developed countries whereby values of $0.54-0.78$ (diets from India, Guatemala or Brazil) v. 0.88-0.94 (diets from North America) have been reported ${ }^{(3)}$. Determination of digestibility at the ileal level is now recognised as being more accurate than its determination at the faecal level ${ }^{(1,4,5)}$, due to the high metabolic activity of the hindgut microflora leading to modification of the undigested dietary AA profile. Most dietary AA are absorbed in the small intestine ${ }^{(6,7)}$, although it remains unclear if the colon may also absorb AA to some degree ${ }^{(8)}$

In humans, ileal digestibility can be determined in subjects with ileostomies $^{(9)}$ or by sampling via a naso-ileal tube ${ }^{(10)}$. None of these methods, however, is suitable for routine application due to technical and economic constraints. Animal models have thus been developed to determine ileal protein digestibility for humans. While the laboratory rat has been considered as a suitable animal model ${ }^{(11)}$, the pig, the digestive tract of which is more similar to that of humans both anatomically and physiologically ${ }^{(12-15)}$, may be a better model for protein digestion in humans ${ }^{(4,16,17)}$. To date, however, only a very few studies have compared protein digestibility directly between pigs and human subjects ${ }^{(18-20)}$, and only one of these ${ }^{(19)}$ has assessed digestibility at the ileal level.

The objective of the present study was to extend the work of Rowan et al. ${ }^{(19)}$ to further evaluate the suitability of the growing pig for predicting dietary ileal $\mathrm{N}$ digestibility in human subjects. Whereas the previous inter-species comparison ${ }^{(19)}$ depended upon a single mixed-protein diet, the present study aimed to expand the comparison to purified protein sources based on an expected highly digestible (casein) and an expected poorly digestible (rapeseed isolate) protein. Hydrolysed casein was also included as part of a wider study, but given the paucity of comparative species data on ileal AA and $\mathrm{N}$ digestibility, digestibility data for hydrolysed casein were also reported here. Ileal digesta were collected via a post-valve T-caecum (PVTC) cannula in pigs and by naso-ileal intubation in human subjects. The protein sources were ${ }^{15} \mathrm{~N}$-labelled to allow determination of the ileal endogenous $\mathrm{N}$ and AA losses, thus allowing for the correction of apparent to true protein digestibility.

\section{Materials and methods}

Test meals

Similar semi-synthetic test meals (Table 1) were prepared for pigs and human subjects. The test meals contained as the sole

Abbreviations: AA, amino acid; BW, body weight; C, intact casein-based; DNFL, dietary nitrogen flow; HC, hydrolysed casein-based; PEG, polyethylene glycol;

PVTC, post-valve T-caecum; R, rapeseed isolate protein-based; TNFL, total nitrogen flow.

* Corresponding author: Professor Paul J. Moughan, fax +64 6350 5655, email p.j.moughan@massey.ac.nz 
respective source of $\mathrm{N}$ a uniformly ${ }^{15} \mathrm{~N}$-labelled intact casein (meal C), a ${ }^{15} \mathrm{~N}$-labelled casein hydrolysate (meal HC; derived from the former casein) or a ${ }^{15} \mathrm{~N}$-labelled rapeseed protein isolate (meal R; Brassica napus L., Goéland cultivar). The $\mathrm{N}$ content ranged from 29.3 to $32.6 \mathrm{~g} / \mathrm{kg}$ diet. ${ }^{15} \mathrm{~N}$-labelled casein (in the form of native calcium phosphocaseinate) was extracted from ${ }^{15} \mathrm{~N}$-labelled milk collected in cows perfused in the rumen with $\left[{ }^{15} \mathrm{~N}\right]$ ammonium sulfate as detailed previously ${ }^{(21)}$. The resulting casein was freeze-dried. Its isotopic enrichment was 0.54 atom\%. A sample of $\left[{ }^{15} \mathrm{~N}\right]$ casein was hydrolysed with pig pancreatin as detailed previously $^{(21)}$. The molecular-weight profile, determined by HPLC gel filtration ${ }^{(21)}$, indicated that $21 \%$ of the peptides were between 1 and $5 \mathrm{kDa}$ in size, and $79 \%$ were less than $1 \mathrm{kDa} .{ }^{15} \mathrm{~N}$-labelled rapeseed protein isolate was obtained from rapeseed fertilised with $\left[{ }^{15} \mathrm{~N}\right]$ ammonium nitrate as described previously ${ }^{(10)}$. Its isotopic enrichment reached $1 \cdot 16$ atom $\%$.

\section{Experimental procedure: pigs}

The pig experiment was conducted according to the guidelines of Massey University, New Zealand and all the experimental procedures were approved by the Massey University Animal Ethics Committee (protocol 05/29).

Eight 10 -week-old Large White $\times$ Duroc entire male pigs were housed individually in steel metabolism crates in a room maintained at $24 \pm 1^{\circ} \mathrm{C}$.

Mean body weight (BW) at the time of surgery (day 0) was 34.4 (SD 2.0) kg. A PVTC cannula was surgically inserted into the caecum of each pig for the collection of ileal digesta ${ }^{(22)}$. The cannulae were made of medical-grade silastic tubing (internal diameter, $24 \mathrm{~mm}$; external diameter, $32 \mathrm{~mm}$ ). The pigs were not fed for $12 \mathrm{~h}$ before surgery. Before the start of surgery, the pigs were given analgesics: carprofen $(3 \mathrm{mg} / \mathrm{kg}$ BW; Pfizer Laboratories Ltd, Manukau, New Zealand), administered by intravenous injection, and methadone $(0.2 \mathrm{mg} / \mathrm{kg}$ BW; David Bull Laboratories, Mulgrave, Victoria, Australia), administered by deep intramuscular injection. Anaesthesia was induced with an intramuscular injection of midazolam (1 mg/kg BW; Roche Products Ltd, Auckland, New Zealand)

Table 1. Ingredient compositions of the test meals fed to growing pigs and adult humans

\begin{tabular}{llll}
\hline & \multicolumn{4}{c}{ Meal $(\mathrm{g} / 100 \mathrm{~g}$ air dry weight $)$} \\
\cline { 2 - 4 } Ingredient & $\mathrm{C}$ & $\mathrm{HC}$ & $\mathrm{R}$ \\
\hline Maltodextrin & $47^{\star} \dagger$ & $46 \dagger$ & $48 \dagger$ \\
Sucrose & 16 & 16 & 16 \\
Oilł & 15 & 15 & 15 \\
{$\left[{ }^{15} \mathrm{~N}\right]$ casein } & 22 & - & - \\
{$\left[{ }^{15} \mathrm{~N}\right]$ hydrolysed casein } & - & 23 & - \\
{$\left[{ }^{15} \mathrm{~N}\right]$ rapeseed protein } & - & - & 21 \\
\hline
\end{tabular}

$\mathrm{C}$, intact casein-based; HC, hydrolysed casein-based; R, rapeseed isolate proteinbased.

* In the pig diets only, $1.8 \mathrm{~g}$ maltodextrin $/ 100 \mathrm{~g}$ diet was replaced by sodium bicarbonate to equalise the dietary electrolyte balance between the $\mathrm{C}$ and $\mathrm{HC}$ diets. This was not done in the human diets, as the sodium bicarbonate rendered the meal unpalatable.

$\dagger \mathrm{In}$ the pig diets only, $0.3 \mathrm{~g}$ maltodextrin $/ 100 \mathrm{~g}$ diet was replaced by titanium dioxide as a dietary marker.

$\ddagger$ Soyabean oil was used in the $\mathrm{C}$ and $\mathrm{HC}$ diets. Rapeseed oil was used in the R diet. and ketamine $(10 \mathrm{mg} / \mathrm{kg}$ BW; Parnell Laboratories Ltd, East Tamaki, New Zealand) followed by an intravenous injection of propofol ( $2 \mathrm{mg} / \mathrm{kg} \mathrm{BW}$; Gensia Laboratories Ltd, Irvine, CA, USA). The anaesthesia was maintained via inhalation of isoflurane (1.5 to 2\%; Merial Ltd, Auckland, New Zealand) in $\mathrm{O}_{2}$. Crystalloids were infused intravenously throughout the anaesthesia period $(5-10 \mathrm{ml} / \mathrm{kg} \mathrm{BW}$ per $\mathrm{h})$ to maintain hydration. Immediately after surgery, the pigs received an intramuscular injection of antibiotic $(2 \mathrm{ml}$; Duplocillin LA, Intervet international B.V., Boxmeer, The Netherlands). For the following $4 \mathrm{~d}$, antibiotic powder (Mamyzim, Boehringer Ingelheim Ltd, Wiri, New Zealand) was dusted on the wound site daily. The site where the cannula was exteriorised was washed with water, and $\mathrm{Zn}$ ointment was applied daily throughout the experiment. The pigs regained consciousness within $1 \mathrm{~h}$ of surgery and were standing $7-8 \mathrm{~h}$ after surgery. There was a $14 \mathrm{~d}$ recovery period before the start of the experiment.

At day 14, the mean BW of the pigs was 39.8 (SD 2.6) kg. During the experimental period (days 14 to 37 ), pigs were fed at a daily level of $0.08 \mathrm{~kg}$ diet $/ \mathrm{kg}$ metabolic BW $\left(\mathrm{kg}^{0.75}\right)$. Except on the digesta collection day, the pigs received three meals daily $(08.00,12.00$ and 16.00 hours) in equal portions. The meals were mixed with water $(1: 1$, w/w) and water was freely available between meals. On the day of digesta collection, the pigs received (09.00 hours) the test meal (a third of the daily portion) mixed with water $(2 \cdot 3: 1, \mathrm{w} / \mathrm{w})$; no other food was then ingested and $200 \mathrm{ml}$ water were given every $30 \mathrm{~min}$ until the end of the digesta collection period (19.00 hours). The pigs received the rest of their daily portion at 19.00 hours (basal meal) and water was then freely available. During the study, the pigs were weighed every sixth day and the level of food intake was adjusted accordingly.

The test meals were administered using a duplicated $4 \times 4$ Latin square design such that every test meal followed each other once only. A fourth test meal was included in the design but was not part of the species comparison. The pigs were randomly allocated to the Latin square and were fed their respective test meals every sixth day after having been fed a basal meal (Table 2) in the intervening $5 \mathrm{~d}$ periods. This was so that the feeding of the test meal was acute (one meal) to afford a similar comparison with human subjects. On the sixth day of each test period, ileal digesta were collected continuously for $10 \mathrm{~h}$ after the ingestion of the test meal using polythene bags attached to the cannula. The bung of the cannula was removed $2 \mathrm{~h}$ before the collection commenced $^{(22)}$ to allow the ileo-caecal valve to protrude into the lumen of the cannula. Digesta collection commenced $30 \mathrm{~min}$ before the ingestion of the test meal in order to determine the basal ${ }^{15} \mathrm{~N}$-enrichment in digesta. The plastic bags, which contained sodium benzoate $(2.3 \mathrm{~mol} / \mathrm{l})$ as a bactericide, were removed every $30 \mathrm{~min}$. Digesta were immediately frozen $\left(-20^{\circ} \mathrm{C}\right)$ after addition of phenylmethylsulfonyl fluoride $(70 \mathrm{mmol} / \mathrm{l})$ as an antiprotease ${ }^{(23)}$. Pig digesta were freeze-dried and finely ground.

\section{Experimental procedure: human subjects}

The human study was conducted according to the guidelines laid down in the Declaration of Helsinki and all procedures involving human subjects were approved by the Institutional 
Table 2. Ingredient composition of the basal meal fed to growing pigs between the test meals

\begin{tabular}{lc}
\hline Ingredient & Basal meal (g/100 g air dry weight) \\
\hline Cooked wheat & 48.43 \\
Sucrose & 17 \\
Casein* & 16 \\
Skimmed milk powder* & 8 \\
Soyabean oil & 8 \\
Dicalcium phosphate & 2 \\
Vitamin-mineral mix $\dagger$ & 0.3 \\
Sodium chloride & 0.16 \\
Synthetic methionine & 0.07 \\
Calcium carbonate & 0.02 \\
Antioxidantł & 0.02 \\
\hline
\end{tabular}

${ }^{\star}$ Acid casein (NZMP, Palmerston North, New Zealand).

†Vitalean (Vitec Nutrition Ltd, Auckland, New Zealand). The mix provided (per $100 \mathrm{~g}$ meal): cholecalciferol, $50.0 \mathrm{mg}$; choline, $8.33 \mathrm{mg}$; niacin, $1.25 \mathrm{mg}$; pantothenic acid, $0.83 \mathrm{mg}$; vitamin $\mathrm{A}, 0.3 \mathrm{~g}$; riboflavin, $0.21 \mathrm{mg}$; vitamin $B_{6}$, $0.17 \mathrm{mg}$; vitamin $\mathrm{E}, 4.27 \mathrm{mg}$; vitamin $\mathrm{K}, 0.17 \mathrm{mg}$; biotin, $0.83 \mu \mathrm{g}$; folic acid, $41.7 \mu \mathrm{g}$; thiamin, $83.3 \mu \mathrm{g}$; vitamin $\mathrm{B}_{12}, 0.83 \mu \mathrm{g}$; Cu, $10.4 \mathrm{mg}$; Fe, $8.3 \mathrm{mg}$; $\mathrm{Mn}$ $3.8 \mathrm{mg}$; Zn, $10 \mathrm{mg}$; I, 83.3 $\mu \mathrm{g}$; Co, $41.7 \mu \mathrm{g}$; Se, $25 \mu \mathrm{g}$.

Review Board for St-Germain-en-Laye Hospital, France. Written informed consent was obtained from all subjects.

Eighteen subjects (nine female, nine male; aged 30 (SD 8) years; mean BW 67 (SD 12) kg; mean BMI 22.5 $(\mathrm{SD} 3.5) \mathrm{kg} / \mathrm{m}^{2}$ ) were included in the study after a thorough medical examination and the conduct of routine blood tests. The volunteers were admitted to hospital for $2 \mathrm{~d}$. In the morning of day 1, a $3 \mathrm{~m}$ polyvinyl chloride (PVC) triple-lumen tube was inserted via the nose under local anaesthesia and then swallowed by the subject so as to progress down the gastrointestinal tract. The progression of the tube was facilitated by inflating through one of the tube's lumens a balloon located at the terminal tip of the tube, after it had passed the pyloric valve. The subjects were then given a standard easily digested hospital meal and received a second meal at 19.00 hours before being food-deprived overnight. The tube was restrained from further movement once it had reached the terminal ileum, as verified under X-ray. On day 2, the protocol commenced at 09.30 hours, when a saline solution ${ }^{(24)}$, containing polyethylene glycol (PEG)-4000 (20 g/l) as a liquid-phase marker for calculation of intestinal fluid flow rate ${ }^{(25)}$, was infused continuously through one of the tube's lumens at a constant rate of $1 \mathrm{ml} / \mathrm{min}$. The test meal was given at 10.00 hours as a liquid drink containing $150 \mathrm{~g}$ test diet and $400 \mathrm{~g}$ deionised water. The study was performed while the subjects were resting in a semi-recumbent position and no food other than the test meal was ingested until the end of the study period. Water was given hourly. Digesta collection commenced $30 \mathrm{~min}$ before the ingestion of the test meal in order to determine the basal ${ }^{15} \mathrm{~N}$-enrichment and lasted for the $8 \mathrm{~h}$ following the ingestion of the meal. Digesta were collected continuously on ice and pooled over $30 \mathrm{~min}$ periods. Digesta were immediately frozen after addition of the antiprotease di-isopropylfluorophosphate $(1 \mathrm{mmol} / \mathrm{l})$. For each pooled sample, a $4 \mathrm{ml}$ sample was kept frozen $\left(-20^{\circ} \mathrm{C}\right)$ for PEG-4000 determination and the remainder was freezedried. Subjects were given meal $\mathrm{R}$ in a separate part of the study which was previously undertaken using exactly the same design as described above ${ }^{(10)}$.

\section{Chemical analysis}

Pig digesta were pooled for each pig and meal type between 4 and $10 \mathrm{~h}$ after meal ingestion ${ }^{(26)}$. Pooled digesta were analysed for $\mathrm{TiO}_{2}$, total $\mathrm{N}$, AA and for ${ }^{15} \mathrm{~N}$-enrichment of total $\mathrm{N}$ and single AA. Diets were analysed for $\mathrm{TiO}_{2}$.

For human subjects, the $30 \mathrm{~min}$ digesta samples were freeze-dried and analysed for $\mathrm{N}$ content and ${ }^{15} \mathrm{~N}$-enrichment. The $30 \mathrm{~min}$ samples were pooled over $8 \mathrm{~h}$ for each meal type and subjected to the analysis of AA and their individual ${ }^{15} \mathrm{~N}$-enrichments.

Protein sources were analysed for AA, total $\mathrm{N}$ and for ${ }^{15} \mathrm{~N}$-enrichment of total $\mathrm{N}$ and single AA.

Total $\mathrm{N}$ and ${ }^{15} \mathrm{~N}$-enrichment were measured on an isotopic ratio MS (Optima; Fisons Instruments, Manchester, UK) coupled to an elemental $\mathrm{N}$ analyser (NA 1500 series 2; Fisons Instruments) ${ }^{(24)}$. AA were determined after acid hydrolysis for $24 \mathrm{~h}$ with $\mathrm{HCl}(6 \mathrm{~mol} / \mathrm{l}$ containing $0.1 \%$ phenol) using a Waters ion exchange HPLC ${ }^{(27)}$. AA were not determined in digesta from animals or human subjects receiving the rapeseed protein as there was insufficient digesta from the human subjects. Cysteine, methionine and tryptophan, being destroyed during acid hydrolysis, were not determined. The ${ }^{15} \mathrm{~N}$-enrichments of individual AA were determined by GC combustion isotope ratio MS (GC-C-IRMS, Finnigan Delta $\mathrm{S}$; Thermo Fisher Scientific Inc., Bremen, Germany) as described previously ${ }^{(28,29)}$. The derivative used here did not allow the determination of ${ }^{15} \mathrm{~N}$-enrichment of arginine. $\mathrm{TiO}_{2}$ was determined using a colorimetric assay after ashing the sample and solubilisation of the minerals ${ }^{(30)}$. PEG-4000 was measured using a turbidimetric method ${ }^{(31)}$.

\section{Data analysis: pig data}

Ileal total N flows (TNFL; g/100g DM intake) were determined for the pooled digesta samples with reference to the dietary marker as follows:

$$
\mathrm{TNFL}_{\text {pig }}=\left(\mathrm{N} \text { in digesta } \times \mathrm{TiO}_{2} \text { in meal }\right) / \mathrm{TiO}_{2} \text { in digesta. }
$$

Ileal dietary $\mathrm{N}$ flows (DNFL; g/100g DM intake) were determined according to the isotope dilution as follows ${ }^{(32)}$.

$$
\mathrm{DNFL}_{\text {pig }}=\mathrm{TNFL}_{\text {pig }} \times\left(\mathrm{E}_{\mathrm{s}}-\mathrm{E}_{0}\right) /\left(\mathrm{E}_{\text {meal }}-\mathrm{E}_{0}\right),
$$

where $E_{s}$ is the ${ }^{15} \mathrm{~N}$-enrichment in the digesta sample, $E_{\text {meal }}$ is the ${ }^{15} \mathrm{~N}$-enrichment in the meal and $\mathrm{E}_{0}$ is the baseline ${ }^{15} \mathrm{~N}$-enrichment in digesta.

Similar equations were used to determine total and dietary AA flows.

Ileal $\mathrm{N}$ digestibility (\%) was calculated as follows:

Apparent ileal digestibility $=(($ dietary Nintake

$$
\text { - TNFL)/dietary Nintake) } \times 100 \text {. }
$$

True ileal digestibility $=(($ dietary $\mathrm{N}$ intake

$$
\text { - DNFL)/dietary N intake) } \times 100 \text {. }
$$

Similar equations were used to determine ileal AA digestibility coefficients. 


\section{Data analysis: human data}

Ileal TNFL (mg per $8 \mathrm{~h}$ ) was determined from the cumulative recovery of total $\mathrm{N}$ for the $8 \mathrm{~h}$ postprandial period using the following equation:

$$
\mathrm{TNFL}_{\text {human }}=\sum_{\mathrm{T}=1}^{16}\left(\mathrm{~N}_{\text {tot-digesta-(T) }} \times \mathrm{DM}_{\mathrm{S}-(\mathrm{T})} \times \mathrm{F}_{\text {tot-(T) }}\right),
$$

where $\mathrm{N}_{\text {tot-digesta-(T) }}$ is the $\mathrm{N}$ content of the digesta sample for the T $30 \mathrm{~min}$ period $(\mathrm{mg} / \mathrm{g}), \mathrm{DM}_{\mathrm{S}-(\mathrm{T})}$ is the DM of the sample $(\mathrm{g} / \mathrm{ml})$ and $F_{\text {tot- }(\mathrm{T})}(\mathrm{ml} / 30 \mathrm{~min})$ is the total ileal liquid flow rate over the $\mathrm{T} 30 \mathrm{~min}$ period. $\mathrm{F}_{\text {tot-(T) }}$ was determined as follows:

$$
\mathrm{F}_{\text {tot-(T) }}=\left(\mathrm{PEG}_{\mathrm{i}} / \mathrm{PEG}_{\mathrm{S}-(\mathrm{T})}\right) \times \mathrm{F}_{\mathrm{i}} \times \mathrm{t}
$$

where $\mathrm{PEG}_{\mathrm{i}}$ and $\mathrm{PEG}_{\mathrm{S}-(\mathrm{T})}$ are the PEG concentrations in the infusion solution and in the digesta sample for the $\mathrm{T} 30 \mathrm{~min}$ period, respectively, $F_{i}$ is the $P E G$ infusion rate $(1 \mathrm{ml} / \mathrm{min})$ and $t$ is the duration of the collection period $(30 \mathrm{~min})$.

DNFL $(\mathrm{mg} / 8 \mathrm{~h})$ was calculated from the cumulative recovery of undigested dietary $\mathrm{N}$ over the $8 \mathrm{~h}$ postprandial period using the following equation:

$$
\begin{aligned}
\mathrm{DNFL}_{\text {human }}= & \sum_{\mathrm{T}=1}^{16}\left(\mathrm{~N}_{\text {tot-digesta-(T) }} \times\left(\left(\mathrm{E}_{\mathrm{S}-(\mathrm{T})}-\mathrm{E}_{0}\right) /\right.\right. \\
& \left.\left.\left(\mathrm{E}_{\text {meal }}-\mathrm{E}_{0}\right)\right) \times \mathrm{F}_{\text {tot- }(\mathrm{T})}\right)
\end{aligned}
$$

where $E_{S-(T)}$ is the ${ }^{15} \mathrm{~N}$-enrichment in the digesta sample for the $30 \mathrm{~min}$ period.

Total AA flow (TAAFL; mg/8h) and dietary AA flow DAAFL; $\mathrm{mg} / 8 \mathrm{~h}$ ) were determined in pooled digesta samples, reconstituted so as to be representative of the total collection, as follows:

$$
\mathrm{TAAFL}=\mathrm{AA}_{\mathrm{s}} \times \mathrm{F} \times \mathrm{DM},
$$

where $\mathrm{AA}_{\mathrm{s}}$ is the $\mathrm{AA}$ content in the pooled digesta sample $(\mathrm{mg} / \mathrm{g}), \mathrm{DM}$ is the DM of the pooled digesta sample $(\mathrm{g} / \mathrm{ml})$ and $\mathrm{F}$ is the total estimated flow rate over $8 \mathrm{~h}(\mathrm{ml} / 8 \mathrm{~h})$.

$$
\mathrm{DAAFL}=\mathrm{TAAFL} \times\left(\mathrm{E}_{\mathrm{s}}-\mathrm{E}_{0}\right) /\left(\mathrm{E}_{\text {meal }}-\mathrm{E}_{0}\right),
$$

where $\mathrm{E}_{\mathrm{s}}$ is the ${ }^{15} \mathrm{~N}$-enrichment of individual $\mathrm{AA}$ in the pooled digesta sample.

Ileal apparent and true digestibilities of $\mathrm{N}$ and AA were determined as described above for the growing pig.

\section{Statistical analysis}

Statistical analyses were performed using SAS (version 9.1; SAS Institute Inc., Cary, NC, USA). The dataset was first subjected to an outlier test ${ }^{(33,34)}$ with $P<0.05$ and was then analysed using the following general linear model:

$$
Y_{i j}=\mu+\alpha_{i}+\beta_{j}+(\alpha \beta)_{i j}+\varepsilon_{i j},
$$

where $Y_{i j}$ is the dependent variable, $\mu$ is the general mean, $\alpha_{i}$ is the fixed effect of the meal, $\beta_{j}$ is the fixed effect of the species and $\varepsilon_{i j}$ is the random residual error. Pearson correlation and simple linear regression analyses were performed on mean pig and human digestibility values for the meals $\mathrm{C}, \mathrm{HC}$, and where applicable for meal R. For AA, mean values for each AA were included in the correlation and regression analyses. Significance was considered to be reached at $P<0.05$.

Results are mean values and standard deviations.

\section{Results}

The pigs remained healthy and grew normally throughout the study, except for one pig that was removed from the study because of internalisation of the cannula. This animal was replaced by a spare cannulated pig of a similar age and BW. Minimal leakage from the PVTC cannula occurred during digesta collections. At post-mortem dissection, no signs of adverse effects due to the cannulation were observed. Mean pig BW at the completion of the trial was $61 \cdot 3$ (SD $4 \cdot 3$ ) $\mathrm{kg}$.

All human subjects completed the trial without complication, and complied with the experimental protocol.

For meals $\mathrm{C}$ and $\mathrm{HC}$ fed to the pigs, one observation each for apparent and true $\mathrm{AA}$ and $\mathrm{N}$ digestibility was removed from the dataset, as detected by application of the outlier test. Similarly, for meal $\mathrm{R}$ fed to the human subjects, one observation for apparent and true $\mathrm{N}$ digestibility was removed from the dataset.

The apparent and true ileal digestibilities of $\mathrm{N}$ for meals $\mathrm{C}$, $\mathrm{HC}$ and $\mathrm{R}$ for pigs and human subjects are given in Table 3. There was a significant $(P<0.05)$ effect of species, with both apparent and true digestibilities being lower in human subjects compared with pigs. The species differences were marked for the apparent digestibility of N (14-16\% lower in human subjects) but were relatively small for true $\mathrm{N}$ digestibility (3-5\% lower in human subjects).

The apparent ileal AA digestibilities for meals $\mathrm{C}$ and $\mathrm{HC}$ for pigs and human subjects are given in Table 4 . For each AA, apparent digestibility was significantly lower $(P<0.05)$ in human subjects compared with pigs, in both meals $\mathrm{C}$ and $\mathrm{HC}$, except for threonine for which the difference did not reach statistical significance.

The true ileal AA digestibility values for meals $\mathrm{C}$ and $\mathrm{HC}$ are given in Table 5. Pig and human true ileal digestibilities were not significantly different $(P>0.05)$ over both meals (C and $\mathrm{HC}$ ) for most AA except for phenylalanine, tyrosine, lysine, histidine and aspartic acid for which digestibilities were significantly lower $(P<0.05)$ for human subjects compared with pigs.

The correlation coefficient between pig and human apparent ileal digestibility was high $(r$ 0.99) but not significant $(P=0.09)$ for $\mathrm{N}$ from meals $\mathrm{C}, \mathrm{HC}$ and $\mathrm{R}$ and was high and statistically significant $(r 0.90 ; P<0.0001)$ for AA from meals $\mathrm{C}$ and $\mathrm{HC}$. The linear regression equation for the AA was $y=1 \cdot 20 x-0.25$, where $y$ is human digestibility and $x$ is pig digestibility.

Similarly, the correlation coefficient between pig and human true ileal digestibility was high $(r 0.98)$ but not significant $(P=0 \cdot 11)$ for $\mathrm{N}$ from meals $\mathrm{C}, \mathrm{HC}$ and $\mathrm{R}$, and was high and statistically significant $(r 0.87 ; P<0.0001)$ for AA from meals $\mathrm{C}$ and $\mathrm{HC}$. Linear regression equations were derived to allow predictions of human true ileal digestibility values from determined pig true ileal digestibility values for $\mathrm{N}$ (Fig. 1(a)) and AA (Fig. 1(b)). 
Table 3. Apparent and true ileal nitrogen digestibility for mixed meals based on intact casein (C), hydrolysed casein (HC) and rapeseed protein isolate (R) fed to adult humans and growing pigs

(Mean values and pooled standard deviations)

\begin{tabular}{|c|c|c|c|c|c|c|c|c|c|c|}
\hline \multirow[b]{2}{*}{$\begin{array}{l}\text { Ileal N } \\
\text { digestibility }\end{array}$} & \multicolumn{2}{|r|}{ Meal C } & \multicolumn{2}{|c|}{ Meal HC } & \multicolumn{2}{|c|}{ Meal $\mathrm{R}$} & \multirow[b]{2}{*}{ Pooled SD } & \multicolumn{3}{|c|}{$P$} \\
\hline & $\begin{array}{l}\text { Pigs } \\
(n 7)\end{array}$ & $\begin{array}{l}\text { Human adults } \\
\qquad(n 6)\end{array}$ & $\begin{array}{l}\text { Pigs } \\
(n 7)\end{array}$ & $\begin{array}{l}\text { Human adults } \\
\qquad(n 5)\end{array}$ & $\begin{array}{l}\text { Pigs } \\
(n 8)\end{array}$ & $\begin{array}{l}\text { Human adults } \\
\qquad(n 6)\end{array}$ & & Meal & Species & Meal $\times$ species \\
\hline Apparent & 0.898 & 0.760 & 0.884 & 0.759 & 0.811 & 0.704 & 0.050 & 0.001 & $<0.001$ & 0.74 \\
\hline True & 0.976 & 0.941 & 0.950 & 0.923 & 0.914 & $0.871^{*}$ & 0.020 & $<0.001$ & $<0.001$ & 0.60 \\
\hline
\end{tabular}

${ }^{*}$ Data originally published by Bos et al. ${ }^{(10)}$.

\section{Discussion}

The objective of the study was to assess the suitability of the growing pig as an animal model for determining the ileal $\mathrm{N}$ digestibility of dietary protein in adult human subjects. Overall, good agreement was found between species for ranking the protein sources, especially regarding true ileal $\mathrm{N}$ digestibility.

The study used methods of digesta collection optimised for each species and for this reason the method of collection was not common across pigs and human subjects, although it was maintained as close as possible and based in both cases on a direct access to ileal fluid as well as the use of ${ }^{15} \mathrm{~N}$-labelled protein sources. In human subjects, ileal digesta were sampled through a naso-ileal triple-lumen tube, allowing digesta collection from subjects with an entire digestive tract, unlike that from ileostomised subjects. The intubation method has been previously used for the determination of ileal $\mathrm{N}$ digestibility in human subjects ${ }^{(35-38)}$ and has been shown to allow more than $50 \%$ of the total digesta to be sampled through the tube and total recovery (about 103\%) of an unabsorbable marker mixed within the meal (A Deglaire, unpublished results). Although it remains unknown whether the oro-ileal transit time is altered by the presence of the tube, previous studies have reported that digesta transit time, and especially gastric emptying rate, do not influence overall ileal protein digestibility ${ }^{(35,39,40)}$. In the present study, ileal digesta were collected from pigs through a PVTC cannula, which, above other cannulation techniques, offers the advantage of leaving the small intestine intact, thus minimising effects on ileal muscle function. The indigestible marker ingested with the test meal was recovered at a rate of 42 (SD 15) \% (data not shown) across the diets $\mathrm{C}, \mathrm{HC}$ and $\mathrm{R}$ in the present pig digesta samples. The less than complete recovery may result from the prescribed period of digesta collection and/or from digesta bypassing the cannula and entering the large intestine. The latter may have differed among pigs resulting in some variability for marker recovery. In the present study, there were no statistically significant correlations found between marker recovery and apparent ileal $\mathrm{N}$ digestibility within diets, which indicates that the pig digesta samples were representative of total ileal digesta ${ }^{(4)}$. Human digesta flow was detected immediately after meal ingestion and was minimal after $8 \mathrm{~h}$, ensuring that the $8 \mathrm{~h}$ collection period was adequate to sample most of the non-digested dietary N. However, relatively high amounts of pig digesta flow were found only $4 \mathrm{~h}$ after the meal as observed previously ${ }^{(26,42)}$ and flow was still substantial $10 \mathrm{~h}$ after meal ingestion. The latter time period $(4-10 \mathrm{~h})$ is likely to correspond to maximal ileal passage of dietary $\mathrm{N}$, previously observed to occur between 3-4 and 9-11 h from ingestion for pea- or wheat-based $\operatorname{diets}^{(26)}$. Thus, although digesta collection times differed between the species, digesta were collected for each species when digesta flows were broadly close to maximal. A species effect inducing different rates of the ${ }^{15} \mathrm{~N}$ tracer recycling

Table 4. Apparent ileal amino acid digestibility for mixed meals based on intact casein (C) or on hydrolysed casein (HC) fed to adult humans and growing pigs

(Mean values and pooled standard deviations)

\begin{tabular}{|c|c|c|c|c|c|c|c|c|}
\hline & \multicolumn{2}{|r|}{ Meal C } & \multicolumn{2}{|c|}{ Meal HC } & \multirow[b]{2}{*}{ Pooled SD } & \multicolumn{3}{|c|}{$P$} \\
\hline & Pigs $(n 7)$ & Human adults $(n 6)$ & Pigs $(n 7)$ & Human adults $(n 5)$ & & Meal & Species & Meal $\times$ species \\
\hline \multicolumn{9}{|c|}{ Essential amino acids } \\
\hline Histidine & 0.908 & 0.808 & 0.848 & 0.691 & 0.058 & 0.001 & $<0.001$ & 0.25 \\
\hline Isoleucine & 0.922 & 0.838 & 0.880 & 0.811 & 0.044 & 0.06 & $<0.001$ & 0.68 \\
\hline Leucine & 0.943 & 0.900 & 0.928 & 0.883 & 0.028 & 0.19 & $<0.001$ & 0.93 \\
\hline Lysine & 0.959 & 0.918 & 0.952 & 0.906 & 0.027 & 0.38 & $<0.001$ & 0.80 \\
\hline Phenylalanine & 0.957 & 0.889 & 0.950 & 0.869 & 0.032 & 0.31 & $<0.001$ & 0.61 \\
\hline Threonine & 0.788 & 0.757 & 0.791 & 0.708 & 0.068 & 0.41 & 0.050 & 0.36 \\
\hline Tyrosine & 0.960 & 0.887 & 0.951 & 0.860 & 0.032 & 0.20 & $<0.001$ & 0.53 \\
\hline Valine & 0.909 & 0.846 & 0.877 & 0.810 & 0.045 & 0.07 & 0.002 & 0.92 \\
\hline \multicolumn{9}{|c|}{ Non-essential amino acids } \\
\hline Alanine & 0.880 & 0.842 & 0.847 & 0.789 & 0.051 & 0.05 & 0.03 & 0.64 \\
\hline Aspartic acid & 0.883 & 0.759 & 0.844 & 0.701 & 0.062 & 0.07 & $<0.001$ & 0.71 \\
\hline Glutamic acid & 0.942 & 0.897 & 0.892 & 0.866 & 0.035 & 0.009 & 0.020 & 0.49 \\
\hline Proline & 0.944 & 0.910 & 0.923 & 0.891 & 0.028 & 0.10 & 0.009 & 0.95 \\
\hline Serine & 0.847 & 0.729 & 0.765 & 0.666 & 0.078 & 0.03 & 0.003 & 0.76 \\
\hline
\end{tabular}


Table 5. True ileal amino acid digestibility for meals based on intact casein (C) or on hydrolysed casein (HC) fed to growing pigs and adult humans (Mean values and pooled standard deviations)

\begin{tabular}{|c|c|c|c|c|c|c|c|c|}
\hline & \multicolumn{2}{|r|}{ Meal C } & \multicolumn{2}{|c|}{ Meal HC } & \multirow[b]{2}{*}{ Pooled SD } & \multicolumn{3}{|c|}{$P$} \\
\hline & Pigs $(n 7)$ & Human adults $(n 6)$ & Pigs $(n 7)$ & Human adults ( $n 5$ ) & & Meal & Species & Meal $\times$ species \\
\hline \multicolumn{9}{|c|}{ Essential amino acids } \\
\hline Histidine & 0.990 & 0.947 & 0.963 & 0.929 & 0.025 & 0.040 & 0.001 & 0.65 \\
\hline Isoleucine & 0.972 & 0.941 & 0.923 & 0.929 & 0.031 & 0.020 & 0.35 & 0.16 \\
\hline Leucine & 0.989 & 0.972 & 0.972 & 0.970 & 0.012 & 0.060 & 0.060 & 0.13 \\
\hline Lysine & 0.993 & 0.974 & 0.982 & 0.976 & 0.011 & 0.320 & 0.010 & 0.17 \\
\hline Phenylalanine & 0.992 & 0.963 & 0.984 & 0.966 & 0.011 & 0.490 & $<0.001$ & 0.21 \\
\hline Threonine & 0.945 & 0.933 & 0.922 & 0.925 & 0.027 & 0.170 & 0.68 & 0.51 \\
\hline Tyrosine & 0.994 & 0.972 & 0.988 & 0.971 & 0.013 & 0.510 & 0.001 & 0.56 \\
\hline Valine & 0.966 & 0.937 & 0.922 & 0.924 & 0.028 & 0.020 & 0.26 & 0.20 \\
\hline \multicolumn{9}{|c|}{ Non-essential amino acids } \\
\hline Alanine & 0.962 & 0.951 & 0.926 & 0.936 & 0.026 & 0.020 & 0.98 & 0.34 \\
\hline Aspartic acid & 0.973 & 0.916 & 0.923 & 0.896 & 0.031 & 0.010 & 0.003 & 0.23 \\
\hline Glutamic acid & 0.975 & 0.940 & 0.920 & 0.914 & 0.029 & 0.002 & 0.10 & 0.22 \\
\hline Proline & 0.979 & 0.962 & 0.956 & 0.954 & 0.017 & 0.030 & 0.16 & 0.26 \\
\hline Serine & 0.931 & 0.870 & 0.835 & 0.826 & 0.060 & 0.009 & 0.17 & 0.29 \\
\hline
\end{tabular}

within endogenous secretions cannot be ruled out. However, overall, tracer recycling had little impact on the relative differences between the species for the true ileal $\mathrm{N}$ digestibility in HC (a diet allowing calculations of tracer recycling), with
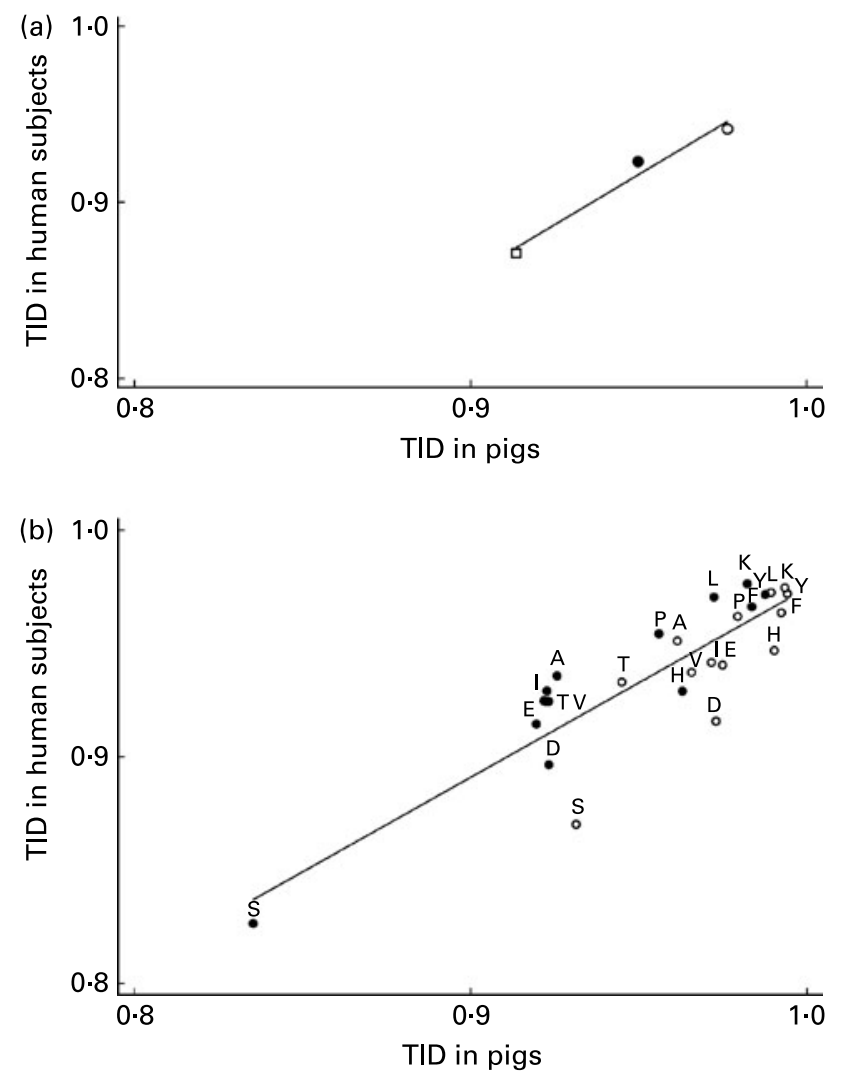

Fig. 1. Linear regression relationships between mean values for human and pig true ileal digestibilities (TID) of (a) nitrogen $\left(y=1.14 x-0.17 ; R^{2} 0.97\right.$; $\left.P_{\text {slope }}=0.11\right)$ and $(b)$ individual amino acids $\left(y=0.83 x+0.14 ; R^{2} 0.76\right.$; $\left.P_{\text {slope }}<0.0001\right)$ for meals based on casein $(O)$ or on hydrolysed casein $(\bullet)$ and, when applicable, for rapeseed protein isolate $(\square)$. A, alanine; D, aspartic acid; $\mathrm{E}$, glutamic acid; $\mathrm{F}$, phenylalanine; $\mathrm{H}$, histidine; I, isoleucine; $\mathrm{K}$, lysine; $\mathrm{L}$, leucine; $\mathrm{P}$, proline; $\mathrm{S}$, serine; $\mathrm{T}$, threonine; $\mathrm{V}$, valine; $\mathrm{Y}$, tyrosine. values after correction for recycling being 0.965 (SD 0.020) and 0.934 (SD 0.010) in pigs and in human subjects, respectively (data not shown).

Of interest in the present study was that the apparent ileal digestibility of $\mathrm{N}$ was markedly lower (14 to $16 \%$ ) for human subjects compared with pigs across the test meals containing different protein sources. The species difference was smaller for apparent AA digestibility, but still substantial, with values being on average $8 \%$ lower for human subjects. The closer agreement observed for apparent digestibilities of AA as compared with those of total $\mathrm{N}$ might arise from differences in non-protein $\mathrm{N}$ transiting in the small intestine between species, such as urea. The acute (no adaptation to the test meal) feeding procedure used in the present work did not appear to influence the results of the study as the present pig apparent $\mathrm{AA}$ and $\mathrm{N}$ digestibility coefficients for $\mathrm{C}$ and $\mathrm{HC}$ were similar to those for the same diets but given to adapted (5d) pigs, being on average only $2.3 \%$ different (A Deglaire and PJ Moughan, unpublished results), such as has been observed previously ${ }^{(9)}$. The presently reported values for the apparent ileal digestibility of $\mathrm{N}$ and AA in casein and hydrolysed casein agree closely with other published values ${ }^{(43-45)}$. Roos et al. ${ }^{(46)}$ reported apparent ileal digestibility values of casein for pigs $(0.76-0.80)$ which were lower than those found in the present study but closer to the values observed here for human subjects. Apparent ileal digestibility values for casein and hydrolysed casein in human subjects have not been reported in the literature. The mean apparent ileal $\mathrm{N}$ digestibility value for rapeseed isolate was in line with that determined in pigs fed dehulled and untoasted rapeseed $(0.76)^{(47)}$. The present differences observed for apparent ileal digestibility between species are likely to be due to a higher proportion of endogenous protein to total ileal protein in human subjects compared with pigs, as true ileal digestibility was much closer between pigs and human subjects (less than $5 \%$ difference for true ileal digestibility of N). Whether the different amount of endogenous protein in digesta is an actual effect of the species or is due to methodological differences is unknown, and should be the topic of further investigation. 
It is more accurate to compare true ileal protein digestibility between species, as this measure represents the specific fate of dietary $\mathrm{N}$ and AA in the digestive tract ${ }^{(1)}$. True ileal digestibilities of $\mathrm{N}$ and of some AA were significantly lower for diet $\mathrm{HC}$ than for diet $\mathrm{C}$. This was observed in both species. It may suggest a lower extent of digestion and/or absorption for HC and/or a higher recycling rate of the ${ }^{15} \mathrm{~N}$ tracer for $\mathrm{HC}$. The exact reason remains unknown but should be investigated further. However, the present study shows a similar ranking among the protein sources $(\mathrm{C}, \mathrm{HC}$ and $\mathrm{R}$ ) between human subjects and pigs and that for most $\mathrm{AA}$ true ileal digestibility ( $\mathrm{C}$ and $\mathrm{HC}$ ) was the same between the species. Although the true ileal digestibility of $\mathrm{N}$ and of five AA was significantly different $(P<0.05)$ between the species, the coefficients were on average only $4 \%$ lower in human subjects compared with pigs. This inter-species difference might result from physiological and/or methodological considerations. The digestive and/or absorptive capacity of the gastrointestinal tract may be greater in pigs than in human subjects, and this may be particularly important for more poorly digested proteins such as rapeseed. Forsum et al. ${ }^{(18)}$ reported a higher $(6 \%)$ true faecal digestibility of vegetable proteins in pigs than in human subjects but similar digestibility of a combination of vegetable and animal proteins between the species.

The degree of correlation between pig and human AA and $\mathrm{N}$ data was high for both apparent and true digestibility values. Correlations for $\mathrm{N}$ data did not reach the level of statistical significance $(P=0.05)$, with $P=0.09$ and $P=0.11$ for apparent and true $\mathrm{N}$ digestibility, respectively. However, correlations for the AA data were statistically significant. The present dataset was augmented by the inclusion of pig and human ileal digestibility data previously reported by Rowan et al. ${ }^{(19)}$ and based on a vegetable-animal proteinbased diet. In the augmented dataset, the correlation between pig and human true ileal digestibility coefficients was high ( $r \quad 0.94)$ and close to significance $(P=0.06)$ for $\mathrm{N}$ from meals $\mathrm{C}, \mathrm{HC}$ and $\mathrm{R}$ and the vegetable-animal-protein-based diet, and was statistically significant $(r 0.83 ; P<0.001)$ for AA from meals $\mathrm{C}$ and $\mathrm{HC}$ and the vegetable-animal protein-based diet. The linear regression equations derived to allow predictions of human true ileal digestibility values from determined pig true ileal digestibility values were $y=1.47 x-0.47$ and $y=1.05 x-0.06$ for $\mathrm{N}\left(R^{2} 0.88\right)$ and for AA $\left(R^{2} 0 \cdot 68\right)$, respectively. Caution needs to be exercised in extrapolating from the predictive equation for true ileal digestibility of $\mathrm{N}$ beyond the range of data collected. The range of $\mathrm{N}$ digestibility assessed here is relatively narrow.

In conclusion, the present results are in general agreement with an earlier observation ${ }^{(19)}$ that there is close agreement between pigs and human subjects for the true ileal digestibility of dietary $\mathrm{N}$. The growing pig has been widely promoted as a useful model for human nutrition studies due to a physiologically and anatomically similar digestive tract ${ }^{(12-15)}$. In addition, the pig unlike the rat has a meal-eating habit ${ }^{(13)}$ and eats most foods consumed by humans. Another advantage with the pig is the possibility for the collection of large samples of representative digesta ${ }^{(14)}$. For all these reasons, the growing pig has been suggested as being a better model than the growing rat for predicting protein digestibility for the adult human ${ }^{(4,17,19)}$. This is supported by our recent data showing a similar true ileal digestibility for rapeseed and milk proteins in the growing rat $(0.955$ (SD 0.011) and 0.956 (SD 0.008), respectively ${ }^{(48)}$ ), unlike what was observed here in both the adult human and the growing pig. Overall, the present findings support the use of the growing pig as an animal model for routine determination of true ileal $\mathrm{N}$ digestibility in human adults, in particular for ranking protein sources.

\section{Acknowledgements}

The study was carried out with the financial support of the Riddet Institute (Palmerston North, New Zealand) and of UMR 914 Nutrition Physiology and Ingestive Behaviour (AgroParisTech/INRA Paris, France). We gratefully acknowledge the Gastroenterology Unit, especially Robert Benamouzig and Gheorge Airinei. We are indebted to Jacques Fauquant (UMR STLO, INRA Rennes, France) for the ${ }^{15} \mathrm{~N}$-labelling of the milk and the casein purification, and Klaus J. Petzke and Shane M. Rutherfurd for their technical assistance.

A. D. designed the study, collected and analysed the data and wrote the manuscript. C. B. assisted in designing the study, collected the data and participated in the writing of the manuscript. D. T. assisted in designing the study. P. J. M. assisted in designing and participated in the writing of the manuscript.

None of the authors had any conflict of interest.

\section{References}

1. Fuller MF \& Tome D (2005) In vivo determination of amino acid bioavailability in humans and model animals. $J A O A C$ Int 88, 923-934.

2. World Health Organization (2007) Protein and Amino Acid Requirements in Human Nutrition. Report of a Joint FAO/ WHO/UNU Expert Consultation. Geneva: WHO.

3. Gilani GS, Cockell KA \& Sepehr E (2005) Effects of antinutritional factors on protein digestibility and amino acid availability in foods. J AOAC Int $\mathbf{8 8 , 9 6 7 - 9 8 7 . ~}$

4. Darragh AJ \& Hodgkinson SM (2000) Quantifying the digestibility of dietary protein. $J$ Nutr 130, 1850S-1856S.

5. Moughan PJ (2003) Amino acid availability: aspects of chemical analysis and bioassay methodology. Nutr Res Rev 16, $127-141$.

6. Krawielitzki K, Zebrowska T, Schadereit R, et al. (1990) Determining of nitrogen absorption and nitrogen secretion in different sections of the pig's intestine by digesta exchange between ${ }^{15} \mathrm{~N}$-labelled and unlabelled animals. Arch Tierernahr 40, 25-37.

7. Fuller MF \& Reeds PJ (1998) Nitrogen cycling in the gut. Annu Rev Nutr 18, 385-411.

8. Blachier F, Mariotti F, Huneau JF, et al. (2007) Effects of amino acid-derived luminal metabolites on the colonic epithelium and physiopathological consequences. Amino Acids 33, 547-562.

9. Moughan PJ, Butts CA, van Wijk H, et al. (2005) An acute ileal amino acid digestibility assay is a valid procedure for use in human ileostomates. J Nutr 135, 404-409.

10. Bos C, Airinei G, Mariotti F, et al. (2007) The poor digestibility of rapeseed protein is balanced by its very high metabolic utilization in humans. $J$ Nutr 137, 594-600.

11. Food and Agriculture Organization (1991) Protein Quality Evaluation in Human Diets. Report of a Joint FAO/WHO Expert Consultation. FAO Food Nutrition Paper, no. 51. Rome: FAO. 
12. WG Pond and KA Houpt (editors) (1978) The Biology of the Pig. New York: Ithaka Comstock Press.

13. Miller ER \& Ullrey DE (1987) The pig as a model for human nutrition. Annu Rev Nutr 7, 361-382.

14. Moughan PJ \& Rowan AM (1989) The pig as a model animal for human nutrition research. Proc Nutr Soc N Z 14, 116-122.

15. Moughan PJ, Birtles MJ, Cranwell PD, et al. (1992) The piglet as a model animal for studying aspects of digestion and absorption in milk-fed human infants. World Rev Nutr Diet 67, 40-113.

16. Moughan PJ, Cranwell PD, Darragh AJ, et al. (1994) The domestic pig as a model animal for studying digestion in humans. In Proceedings of the VIth International Symposium on Digestive Physiology in Pigs, vol. 80, pp. 389-396 [WB Souffrant and H Hagemeister, editors]. Bad Doberan, Germany: EAAP Publ.

17. Moughan PJ (2005) Dietary protein quality in humans - an overview. J AOAC Int 88, 874-876.

18. Forsum E, Goranzon H, Rundgren M, et al. (1981) Protein evaluation of mixed diets. Comparative study in man and in the pig and rat of vegetable-animal and vegetable protein diets. Ann Nutr Metabol 25, 137-150.

19. Rowan AM, Moughan PJ, Wilson MN, et al. (1994) Comparison of the ileal and faecal digestibility of dietary amino acids in adult humans and evaluation of the pig as a model animal for digestion studies in man. Br J Nutr 71, 29-42.

20. Darragh AJ \& Moughan PJ (1995) The three-week-old piglet as a model animal for studying protein digestion in human infants. J Pediatr Gastroenterol Nutr 21, 387-393.

21. Deglaire A, Moughan PJ, Bos C, et al. (2008) A casein hydrolysate does not enhance gut endogenous protein flows compared with intact casein when fed to growing rats. J Nutr 138, $556-561$.

22. van Leeuwen P, van Kleef DJ, van Kempen GJM, et al. (1991) The post valve T-caecum cannulation technique in pigs applicated (sic) to determine the digestibility of amino acid in maize, groundnut and sunflower meal. J Anim Physiol Anim Nutr 65, 183-193.

23. Salgado P, Freire JPB, Mourato M, et al. (2002) Comparative effects of different legume protein sources in weaned piglets: nutrient digestibility, intestinal morphology and digestive enzymes. Livest Prod Sci 74, 191-202.

24. Gausserès N, Mahé S, Benamouzig R, et al. (1997) $\left[{ }^{15} \mathrm{~N}\right]$-labeled pea flour protein nitrogen exhibits good ileal digestibility and postprandial retention in humans. J Nutr 127, $1160-1165$.

25. Modigliani R, Rambaud JC \& Bernier JJ (1973) The method of intraluminal perfusion of the human small intestine. I. Principle and technique. Digestion 9, 176-192.

26. Leterme P, Thewis A, Francois E, et al. (1996) The use of ${ }^{15} \mathrm{~N}$-labeled dietary proteins for determining true ileal amino acid digestibilities is limited by their rapid recycling in the endogenous secretions of pigs. J Nutr 126, 2188-2198.

27. Association of Analytical Communities (2003) Official Methods of Analysis of AOAC International, 17th ed., 2nd revision Gaithersburg, MD: AOAC.

28. Metges CC, Petzke KJ \& Hennig U (1996) Gas chromatography/combustion/isotope ratio mass spectrometric comparison of N-acetyl- and N-pivaloyl amino acid esters to measure ${ }^{15} \mathrm{~N}$ isotopic abundances in physiological samples: a pilot study on amino acid synthesis in the upper gastro-intestinal tract of minipigs. J Mass Spectrom 31, 367-376.

29. Petzke KJ, Feist T, Fleig WE, et al. (2006) Nitrogen isotopic composition in hair protein is different in liver cirrhotic patients. Rapid Commun Mass Spectrom 20, 2973-2978.
30. Short FJ, Gorton P, Wiseman J, et al. (1996) Determination of titanium dioxide added as an inert marker in chicken digestibility studies. Anim Feed Sci Technol 59, 215-221.

31. Hyden S (1955) A turbidimetric method for the determination of higher polyethylene glycols in biological materials. Ann R Agric Coll 21, 139-145.

32. Hess V, Ganier P, Thibault JN, et al. (2000) Comparison of the isotope dilution method for determination of the ileal endogenous amino acid losses with labelled diet and labelled pigs. Br J Nutr 83, 123-130.

33. Dixon WJ (1950) Analysis of extreme values. Ann Math Statist 21, 488-506.

34. Dixon WJ (1953) Processing data for outliers. Biometrics 9, $74-89$.

35. Gaudichon C, Mahé S, Benamouzig R, et al. (1999) Net postprandial utilization of ${ }^{15} \mathrm{~N}$-labeled milk protein nitrogen is influenced by diet composition in humans. J Nutr 129, 890-895.

36. Gausserès N, Mahé S, Benamouzig R, et al. (1996) The gastroileal digestion of ${ }^{15} \mathrm{~N}$-labelled pea nitrogen in adult humans. $B r J$ Nutr 76, 75-85.

37. Mariotti F, Mahé S, Benamouzig R, et al. (1999) Nutritional value of ${ }^{15} \mathrm{~N}$-soy protein isolate assessed from ileal digestibility and postprandial protein utilization in humans. J Nutr $\mathbf{1 2 9}$, 1992-1997.

38. Bos C, Juillet B, Fouillet H, et al. (2005) Postprandial metabolic utilization of wheat protein in humans. Am J Clin Nutr 81, 87-94.

39. Weber E \& Ehrlein HJ (1998) Relationships between gastric emptying and intestinal absorption of nutrients and energy in mini pigs. Dig Dis Sci 43, 1141-1153.

40. Mariotti F, Mahé S, Luengo C, et al. (2000) Postprandial modulation of dietary and whole-body nitrogen utilization by carbohydrates in humans. Am J Clin Nutr 72, 954-962.

41. van Leeuwen P, Veldman A, Boisen S, et al. (1996) Apparent ileal dry matter and crude protein digestibility of rations fed to pigs and determined with the use of chromic oxide $\left(\mathrm{Cr}_{2} \mathrm{O}_{3}\right)$ and acid-insoluble ash as digestive markers. $\mathrm{Br} J$ Nutr 76, $551-562$

42. Hodgkinson SM, Moughan PJ, Morel PCH, et al. (2002) The diurnal pattern of ileal dry matter and endogenous ileal nitrogen flows in the growing pig. $J$ Sci Food Agric 82, 1860-1866.

43. Chung TK \& Baker DH (1992) Apparent and true amino acid digestibility of a crystalline amino acid mixture and of casein: comparison of values obtained with ileal-cannulated pigs and cecectomized cockerels. J Anim Sci 70, 3781-3790.

44. Nyachoti CM, deLange CFM \& Schulze H (1997) Estimating endogenous amino acid flows at the terminal ileum and true ileal amino acid digestibilities in feedstuffs for growing pigs using the homoarginine method. $J$ Anim Sci 75, 3206-3213.

45. Yin YL, Huang RL, Libao-Mercado AJ, et al. (2004) Effect of including purified jack bean lectin in casein or hydrolysed casein-based diets on apparent and true ileal amino acid digestibility in the growing pig. Anim Sci 79, 283-291.

46. Roos N, Pfeuffer M \& Hagemeister H (1994) Labeling with ${ }^{15} \mathrm{~N}$ as compared with homoarginine suggests a lower prececal digestibility of casein in pigs. J Nutr 124, 2404-2409.

47. Grala W, Verstegen MW, Jansman AJ, et al. (1998) Ileal apparent protein and amino acid digestibilities and endogenous nitrogen losses in pigs fed soybean and rapeseed products. J Anim Sci 76, 557-568.

48. Boutry C, Chevalier L, Fouillet H, et al. (2008) Effect of rapeseed protein on tissue postprandial protein metabolism in rats. Proc Nutr Soc 67, E201. 